\title{
Measuring Determinants and Effects of Firms' Financial Structure in a Deleverage Setting: Evidence From Italy
}

\author{
Mario Mustilli ${ }^{1}$, Francesco Campanella ${ }^{1}$ \& Eugenio D’Angelo ${ }^{2}$ \\ ${ }^{1}$ Department of Economics, University of Campania “Luigi Vanvitelli”, Capua, Italy \\ ${ }^{2}$ Department of Economics and Legal Studies, Pegaso Telematic University, Naples, Italy \\ Correspondence: Eugenio D’Angelo, Department of Economics and Legal Studies, Pegaso Telematic University, \\ Naples, Italy.
}

Received: February 10, 2018

Accepted: February 23, 2018

Online Published: March 2, 2018

doi:10.5430/ijfr.v9n2p23

URL: https://doi.org/10.5430/ijfr.v9n2p23

The corresponding author has previously presented the paper at the 5th BSLab Symposium 2018 - "Cocreating Responsible Futures in the Digital Age".

\begin{abstract}
Since 2011, after ten year of growth, Italian non-financial firms have heavily reduced their bank debt. Indeed, the ratio between bank credit to non-financial sector and the Italian GDP decreased from 92.5\% to 83.5\% in the last five years. This paper examines the determinants of this reduction using an OLS regression model performed on a sample of 12,974 Italian firms. In addition, we analyse the effect of this change in the capital structure on profitability and on debt-service. Results show that Growth, Size, Tangibility and Profitability are associated with leverage, consistently with the previous literature. Furthermore, we found that firm reduced their return on equity but improved their cash flow to debt ratio.
\end{abstract}

Keywords: net financial position, capital structure, bank, deleverage

\section{Introduction and Motivation of the Paper}

Following the two crises that hit the world financial system in 2007 and 2011, there has been a progressive deleveraging process involving non-financial corporations operating in the euro area.

After about a decade of growth in the use of financial debt, in the second half of 2009, companies began to reduce this level of indebtedness. This circumstance can be seen analysing data provided by the Bank of International Settlements regarding the ratio between the European non-financial corporation's financial debt and the GDP. Data show that the system raised this ratio from $80.1 \%$ (in 1999) to $106.3 \%$ (in 2009). The debt expansion then encountered a gradual contraction that has been consumed since 2009 onwards. This contraction is also extremely clear by observing the same ratio in 2016 (91.5\%). If we analyse this process in the Italian setting, where firms are historically used to be under capitalized ad heavily dependent on bank debt in their capital structure, the deleverage is definitely important as well. Since 2011 the ratio between credit to non-financial sector and GDP decreased from $92.5 \%$ to $83.5 \%$ (Figure 1 ).

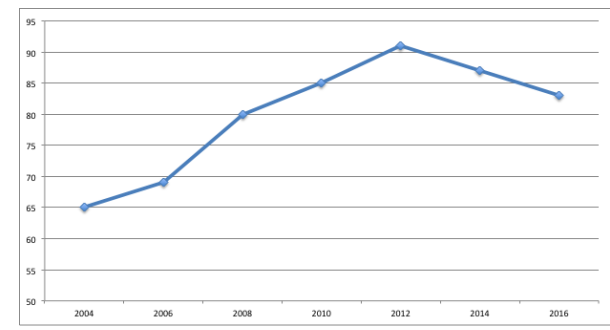

Figure 1. Bank credit to non-financial corporations in Europe

Source: https://www.bis.org 
The deleveraging we are witnessing is undoubtedly a central issue for business scholars as well as for banking and macroeconomics researchers; therefore it gave us a strong motivation to deeply investigate this phenomenon.

From the point of view of corporate finance, it is clear that the period of deleveraging can be the perfect field in which testing some of the most well-established theories on the financial structure, from the pecking order theory to the trade-off one, as well as, from a more strictly applicative point of view, the dynamics of the financial structure can be analysed regarding their relationship with the business performances and corporate investments.

With reference to the banking sector, it is evident that a progressive process of deleverage in non-financial corporations is reflected in banks lending decisions. In this light, the effects of deleveraging are of great interest both in terms of composition of banks assets and in terms of profitability and risk of the banking system.

On the macroeconomic side, the bank-enterprise relationship is relevant to a variety of aspects. In first instance, the circumstance that firms are less bank-lending dependent, opens the discussion on the capability that firms have to financially support new investments, which may lead to higher employment of the Eurozone. This issue is taking more and more momentum since we are witnessing a concomitant process, in particular in some European countries, of contraction in the public deficit and of reduction in the value of real estate assets and government bonds (the typical savings allocation). This circumstance may result in a reduction in other potential classical external sources of funding (public contribution and equity) which, combined with a reduction in bank lending, are likely to strongly limit the ability of firms to promote new investments and thus to develop their own revenues. In addition, the eventuality that financial constraint could limit new investment and hence employment, has undeniable implications also in maintaining inflation at the desirable level of $2 \%$ and in achieving a sustainable relationship between public debt and GDP.

Regardless the described effects both at firm, bank and macroeconomic level, it is clear that the reduction of bank lending to non-financial corporations can have a double origin, a supply side and a demand side one (Figure 2).

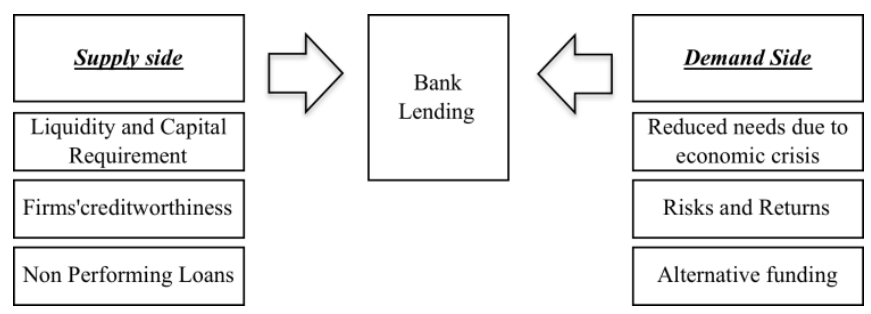

Figure 2. Origin of the deleveraging process

A first cause of bank credit reduction could be attributable to banks willingness and capability to finance the non-financial sector. In other words, debt reduction could have been caused by the increasingly stringent regulation to protect the banking system. The Basel II and Basel III agreements may have led to a contraction in bank lending as a result of the need for banks to ensure the compliance with Liquidity Cover Ratio, Net Stable Funding Ratio and Capital Requirements (Gangi \& Campanella 2006; Mustilli et al. 2017). Furthermore, banks may have reduced their expectations on firms' creditworthiness and therefore reduced the amount of credit to firms that were more likely to go bankrupt. Moreover, banks have recently faced a period characterized by an increase in non-performing loans that may have contributed to enhance their risk aversion. On the other hand, from a demand side point of view, the reduction of bank-debt to corporations could also have been due a change in the needs of businesses. The economic crisis we've witnessed has in fact led to a decrease in corporate revenues with the possible effect of reducing the need for working capital financing. Usually, a reduction in revenues is accompanied by a reduction in receivables and a reduction in inventories. This contraction in the working capital may have produced a changed need for short-term bank credit and hence produced a short-term demand side and non-supply side deleverage. On the other hand, the reasons that may have caused a reduction in long-term financing are different. A reduction in the revenues of businesses cannot have led to a reduction in corporate long-term assets (which are known to be less responsive to operating activities reductions). The financial debt obtained to support long-term investments may not have had the time to be properly served. The logical consequence of a contraction in revenues would not result, therefore, in a reduction of long-term asset, but in a problem of debt duration and repayment. Therefore, a contraction in long-term debt may have been determined by an enterprise need to well match EBITDA and debt-service, thus asking banks to 
increase debt duration. Consequently, this need, in the case of a reduction in long-term debt, could only have been achieved through an equity increase. Therefore, when evaluating the deleverage process, is important to measure both the reduction in short and long term debt.

The aim of the research, therefore, is to investigate, through an explorative study, the trend of the financial debt in Italian non-financial corporations, analysing the evolution of key leverage ratios. Subsequently, in a context of reduction of such sources of funding, the purpose is to investigate the determinants of such a change in the financial structure at firm level, according to the most relevant previous theoretical and empirical studies. Furthermore we will compare financial performances obtained by firms before and after deleverage.

The paper falls into four further sections. In section number two we will present the literature review. In the third section we will describe the sample and the methodology. In the subsequent section we will present results and discuss them. The last section is dedicated to conclusions, including limitations of the study and further research directions.

\section{Literature Review}

Capital structure and firm's choices concerning the optimal level of financial debt are well-addressed issues in the field of corporate finance, both theoretically and empirically. Since the seminal work of Modigliani and Miller (1958), whose main preposition stated the irrelevance of the capital structure under the hypotheses of market perfection, several theories have been developed. The pecking order theory states that there is a hierarchy that firm follows when deciding how to finance their activities (Myers and Majluf, 1984). The trade off theory, on the other hand, states that the optimal debt-equity ratio can be achieved when the tax advantage of debt is offset by the costs of financial distress, thus minimizing the cost of market imperfection (Kraus and Litzenberger, 1973). Coherently with the purpose of this paper, we will not further examine the mentioned and well known theories, but we will only focus on the variables employed in the present study as determinants of firms' leverage choices, giving an explanation about the expected results according to previous literature.

Many previous studies suggest that the capital structure can be influenced by firm size. As mentioned by, Among others, Gruber and Warner (1977), Ang, Chua and McConnel (1982) and Titman and Wessels (1988), bankruptcy costs increase when firm size decreases. In addition, when firms become larger, they are more likely to be more diversified and, therefore, the probability of bankruptcy decreases. Furthermore, large firms, that usually have also a higher disclosure, can take advantage of this lower risk profile obtaining a lower cost of debt.

With reference to firm growth, previous studies have highlighted that, due to the agency role of debt (Jensen and Meckling, 1976), firms with higher growth opportunities are more likely to be equity financed instead of increasing their financial debt. Indeed, when firms grow, they usually have higher cash flows and better investing opportunities, thus, in this circumstance, the typical conflict between principal and agent should decrease. Contrariwise, when firms have lower growth opportunities, leverage will discipline the opportunistic behavior of mangers and induce firms to increase the level of debt in order to motivate managers to more effectively run the businesses.

Assets tangibility is another typical variable that may affect capital structure choices. Due to the collateralization of their assets, firms with a higher value of tangible assets should increase their leverage. This circumstance can be explained by the fact that, issuing debt secured by property with a known value, firms can have an easier access to credit and a lower cost of capital because banks reduce their risk and their monitoring costs (Jensen and Meckling, 1976; Myers and Majluf, 1984; Grossman and Hart, 1982).

According to DeAngelo and Masulis (1980) non-debt-related corporate tax shields (NDTS) are negatively related to financial leverage. The theoretical explanation of this hypothesis states that tax deduction that come from investing activities, such as depreciations, can substitute tax advantages that originate from financial debt because firms may have a lower incentive to get other taxes advantages.

According to the pecking order theory (Myers, 1977; Titman and Wessel, 1988; Rajan and Zingales, 1995) firms are more likely to finance their activities through internal resources (retained earnings), secondly from debt and finally issuing new equity. This hierarchical order of choice regarding the sources of financing is mainly connected to the cost of these sources of financing. In fact, new shares and debt, as a result of higher transaction costs and information asymmetries, represent the least cost-effective solutions. Therefore, when the company has higher levels of profitability, it will be more likely to finance its activities with self-financing.

Many authors have found that firm's debt level is a negatively associated with earning volatility. Higher volatility of earnings increases the probability of bankruptcy and firms, thus increasing the cost of debt and the probability of being rejected when applying for a loan (Jensen, 1986). 


\section{Materials and Method}

As far as the deleverage period was concerned, we focused our analysis on a 5 year period (2012-2016). The sample used for our empirical analysis included 12.974 non-financial firms. Therefore, our dataset included 64.870 yearly observations, which have been analysed with a panel data methodology. Furthermore, we included in the sample only limited and unlisted companies still active to date (2016) and for which all the data needed for the analysis were available. In the light of our research questions and taking in account the type of variables employed in the analysis, we first performed a correlation analysis between the variables, then we used a linear multiple regression analysis (OLS) and finally we performed a T-Test to compare performance achieved in the period of deleverage (2012-2016) to the ones achieved in the previous period (2007-2011). Our data analysis was conducted using the SPSS statistics 17.0 software.

Our analysis consists of three regression models, one for each of the following dependent variables:

1) Total_NFP $=($ Short Term Bank Debt + Long Term Bank Debt - Liquidity $) /$ Total Assets

2) ShortTerm_NFP = (Short Term Bank Debt- Liquidity) $/$ Total Assets

3) LongTerm_Debt $=$ Long Term Bank Debt / Total Assets

Our independent variables, consistently with the previous literature concerning capital structure, are defined as follows:

4) Size $=$ Ln (Total Assets)

5) Growth $=\%$ variation in Total Assets

6) Tangibility $=$ Tangible Assets / Total Assets

7) N.D.T.S. $=$ Depreciation $/$ Total Assets

8) Profitability = R.O.A.

9) Volatility $=$ Standard Deviation of $\%$ change in operating income

Our fixed affect panel model may be presented as follows:

$$
Y_{i}=\beta_{1} \text { Size }_{i}+\beta_{2} \text { Growth }_{i}+\beta_{3} \text { Tangibility }_{i}+\beta_{4} \text { N.D.T.S. }{ }_{. i}+\beta_{5} \text { Profitability }_{i}+\beta_{6} \text { Volatility }_{i}+u_{i}
$$

Where, of course, $u_{i}$ is the error term. Furthermore, we employed in the study two control dummy variables to check for year's effect and to control for geographical differences. Since years are binary variables we had (n-1) entities included in the model. The $\mathrm{G}$ variable is a dummy variable that takes the value of 1 if the firm is located in the north of Italy and 0 otherwise. We decided to include this variable in the model because in Italy there is a great concern about the differences between northern and southern economy.

\section{Results and Discussion}

Before introducing the correlation analysis, regression models and the T-tests, we believe it is appropriate to show the descriptive statistics regarding the sample, through some graphs that seem to us to be particularly illustrative. In the first graph reported above is shown the trend in the Short-term NFP, in the Total NFP and in the Long-term bank debt. It is definitely clear from the picture that the total amount of bank debt has considerably reduced since 2011.

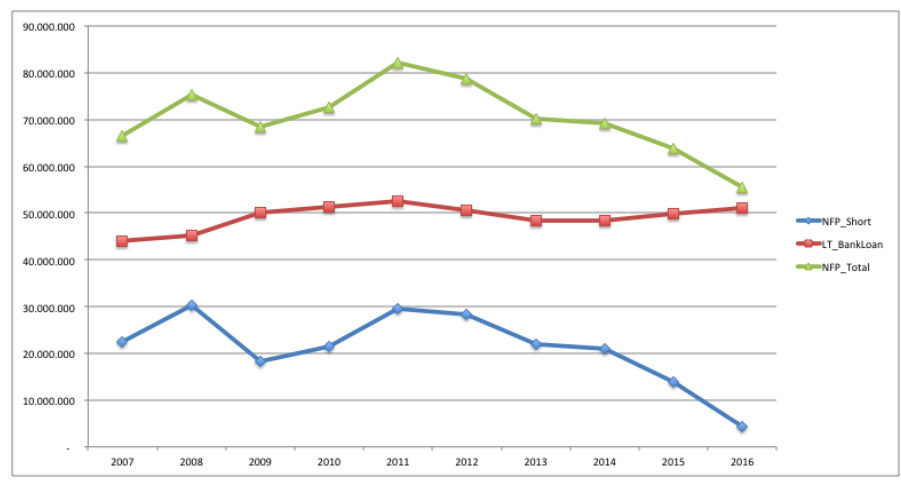

Figure 3. The evolution of the bank debt in the total sample (Euro/1000) 
However, while the Short-term NFP decreases, the Long-term debt remains substantially constant. This circumstance can be explained by what we've mentioned in the introduction of the paper that is that firms may have negotiated with banks a longer duration for their short-term debt, in order to have a more balanced ratio between cash flows and debt service. Moreover, this circumstance is supported by the trend of the total asset in the same period. As shown in the graph reported above, the total assets have increased since 2011 and that means that firms hadn't face a reduction in the capital employed (Figure 4).

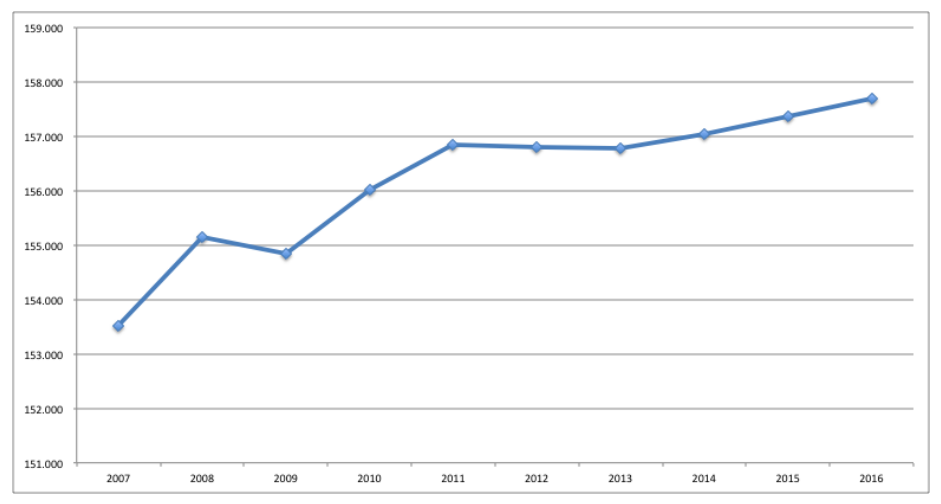

Figure 4. The evolution of the natural log of total assets

As far as the geographical difference is concerned, we believe that the following two graphs could be useful to confirm the trend in the NFP differentiating between data of firms operating in the north (on the left side) and in the south (on the right side) of Italy. As you can see the trend is similar even if the short-term NFP decreases significantly more in the north of Italy.
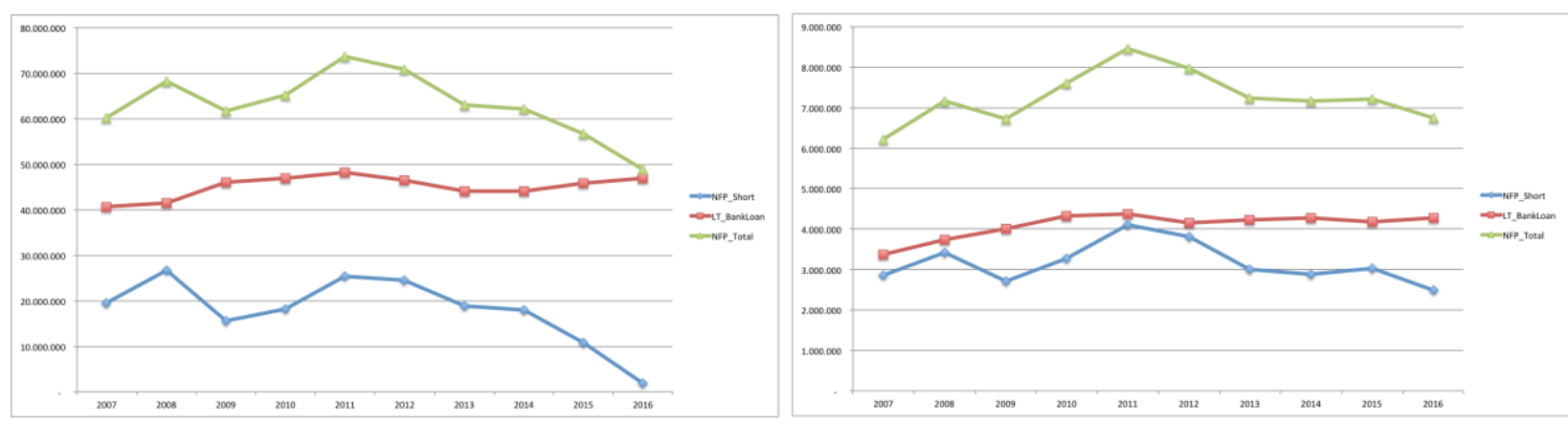

Figure 5. The evolution of the bank debt (Euro/1000) in the north and in the south of Italy

The correlation table (table 1) shows that there are some significant relationships between the independent variables, even if not so high to generate a multicollinearity issue. Anyway we checked the variance inflation factor and results shows that there were no values exceeding the critical value of 5 (Table 2). More in details we found that the highest positive and significant correlation between were the following: profitability and growth, volatility and tangibility, volatility and NDTS and NDTS and tangibility. The highest negative and significant correlation between the independent variables has been found between profitability and tangibility. 
Table 1. Correlation matrix

\begin{tabular}{|c|c|c|c|c|c|c|c|c|c|c|c|}
\hline & & & \multirow[b]{2}{*}{ Size } & \multirow[b]{2}{*}{ Growth } & \multirow[b]{2}{*}{ Tangibility } & \multirow[b]{2}{*}{ NDTS } & \multirow[b]{2}{*}{ Profitability } & \multirow[b]{2}{*}{ Volatility } & \multicolumn{3}{|c|}{ Dependent Variables } \\
\hline & & & & & & & & & Total_NFP & ShortTerm_NFP & LongTerm_Debt \\
\hline & \multirow[t]{4}{*}{ Size } & Pearson & 1 &, $077^{* * * *}$ &, $081^{* * * *}$ & $021^{* * *}$ &,$- 048^{* * *}$ & .005 &, $098^{* * *}$ &, $080^{* * *}$ &, $087^{* * *}$ \\
\hline & & Correlation & & & & & & & & & \\
\hline & & $\begin{array}{l}\text { Sig. } \\
\text { (2-tailed) }\end{array}$ & & .000 & .000 & .000 & .000 & .210 & .000 & .000 & .000 \\
\hline & & $\mathrm{N}$ & 64870 & 64870 & 64870 & 64870 & 64870 & 64870 & 64870 & 64870 & 64870 \\
\hline & \multirow[t]{4}{*}{ Growth } & Pearson &, $077^{* * *}$ & 1 &,$- 017^{* *}$ & .008 & 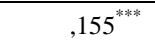 & -.008 &,$- 025^{\text {***k }}$ & 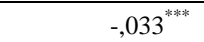 &, $013^{\text {**** }}$ \\
\hline & & Correlation & & & & & & & & & \\
\hline & & $\begin{array}{l}\text { Sig. } \\
\text { (2-tailed) }\end{array}$ & .000 & & .000 & .066 & .000 & .059 & .000 & .000 & .002 \\
\hline & & $\mathrm{N}$ & 64870 & 64870 & 64870 & 64870 & 64870 & 64870 & 64870 & 64870 & 64870 \\
\hline & \multirow[t]{4}{*}{ Tangibility } & Pearson &, $081^{* * *}$ &,$- 017^{\text {*** }}$ & 1 & $272^{* * *}$ &,$- 162^{* * *}$ &, $274^{* * *}$ & $164^{* * * *}$ &, $085^{* * *}$ &, $291^{* * * *}$ \\
\hline & & Correlation & & & & & & & & & \\
\hline & & $\begin{array}{l}\text { Sig. } \\
\text { (2-tailed) }\end{array}$ & .000 & .000 & & .000 & .000 & .000 & .000 & .000 & .000 \\
\hline & & $\mathrm{N}$ & 64870 & 64870 & 64870 & 64870 & 64870 & 64870 & 64870 & 64870 & 64870 \\
\hline & \multirow[t]{4}{*}{ NDTS } & Pearson &, $021^{* * * *}$ & .008 &, $272^{* * *}$ & 1 &, $088^{* * * *}$ &, $292^{* * *}$ &,$- 055^{* * *}$ &,$- 115^{* * *}$ & $156^{* * *}$ \\
\hline & & Correlation & & & & & & & & & \\
\hline & & $\begin{array}{l}\text { Sig. } \\
\text { (2-tailed) }\end{array}$ & .000 & .066 & .000 & & .000 & .000 & .000 & .000 & .000 \\
\hline & & $\mathrm{N}$ & 64870 & 64870 & 64870 & 64870 & 64870 & 64870 & 64870 & 64870 & 64870 \\
\hline & \multirow[t]{4}{*}{ Profitability } & Pearson &,$- 048^{* * *}$ &, $155^{* * * *}$ &,$- 162^{* * *}$ &, $088^{* * *}$ & 1 &,$- 020^{* * * *}$ &,$- 289^{* * * *}$ &,$- 284^{* * *}$ &,$- 118^{* * *}$ \\
\hline & & Correlation & & & & & & & & & \\
\hline & & $\begin{array}{l}\text { Sig. } \\
\text { (2-tailed) }\end{array}$ & .000 & .000 & .000 & .000 & & .000 & .000 & .000 & .000 \\
\hline & & $\mathrm{N}$ & 64870 & 64870 & 64870 & 64870 & 64870 & 64870 & 64870 & 64870 & 64870 \\
\hline & \multirow[t]{4}{*}{ Volatility } & Pearson & .005 & -.008 &, $274^{* * *}$ &, $292^{* * *}$ &,$- 020^{* * *}$ & 1 &, $015^{\text {*** }}$ &,$- 039^{* * * *}$ & $164^{* * * *}$ \\
\hline & & Correlation & & & & & & & & & \\
\hline & & $\begin{array}{l}\text { Sig. } \\
\text { (2-tailed) }\end{array}$ & .210 & .059 & .000 & .000 & .000 & & .000 & .000 & .000 \\
\hline & & $\mathrm{N}$ & 64870 & 64870 & 64870 & 64870 & 64870 & 64870 & 64870 & 64870 & 64870 \\
\hline \multirow{10}{*}{ 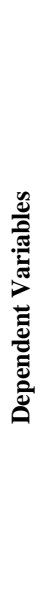 } & \multirow[t]{4}{*}{ Total_NFP } & Pearson &, $098^{* * * *}$ &,$- 025^{* * * *}$ &, $164^{* * *}$ &,$- 055^{\text {*** }}$ &,$- 289^{* * * k}$ &, $015^{* * *}$ & 1 &, $955^{\text {*** }}$ &, $502^{* * * *}$ \\
\hline & & Correlation & & & & & & & & & \\
\hline & & $\begin{array}{l}\text { Sig. } \\
\text { (2-tailed) }\end{array}$ & .000 & .000 & .000 & .000 & .000 & .000 & & .000 & .000 \\
\hline & & $\mathrm{N}$ & 64870 & 64870 & 64870 & 64870 & 64870 & 64870 & 64870 & 64870 & 64870 \\
\hline & \multirow[t]{3}{*}{$\begin{array}{l}\text { ShortTerm_ } \\
\text { NFP }\end{array}$} & $\begin{array}{l}\text { Pearson } \\
\text { Correlation }\end{array}$ &, $080^{* * * *}$ &,$- 033^{* * * *}$ &, $085^{* * * *}$ &,$- 115^{* * *}$ &,$- 284^{* * * *}$ &,$- 039^{* * * *}$ &, $955^{\text {*** }}$ & 1 & $224^{* * * *}$ \\
\hline & & $\begin{array}{l}\text { Sig. } \\
\text { (2-tailed) }\end{array}$ & .000 & .000 & .000 & .000 & .000 & .000 & .000 & & .000 \\
\hline & & $\mathrm{N}$ & 64870 & 64870 & 64870 & 64870 & 64870 & 64870 & 64870 & 64870 & 64870 \\
\hline & \multirow[t]{3}{*}{$\begin{array}{l}\text { LongTerm_ } \\
\text { Debt }\end{array}$} & $\begin{array}{l}\text { Pearson } \\
\text { Correlation }\end{array}$ &, $087^{* * * *}$ &, $013^{* * * *}$ &, $291^{* * * *}$ & $156^{* * *}$ &,$- 118^{* * *}$ &, $164^{* * * *}$ &, $502^{* * * *}$ &, $224^{* * *}$ & 1 \\
\hline & & $\begin{array}{l}\text { Sig. } \\
\text { (2-tailed) }\end{array}$ & .000 & .002 & .000 & .000 & .000 & .000 & .000 & .000 & \\
\hline & & $\mathrm{N}$ & 64870 & 64870 & 64870 & 64870 & 64870 & 64870 & 64870 & 64870 & 64870 \\
\hline
\end{tabular}

Sign level: $1 \%(* * *) ; 5 \%(* *)$

After performing the correlation analysis, as mentioned in the method section, we employed three fixed effect regression models. All the models used the same independent variables but different dependent variables. In the first model we used the Total NFP as a dependent variable, in the second model we used the Short Term NFP as a dependent variable and in the last one we used the Long Term bank debt as a dependent variable. All the models 
resulted significant with a value below 0.01 , explaining approximately the $11 \%$ of the variance in the dependent variable. The main results of our study show that size and tangibility have a positive effect on the NFP and that growth and profitability have a negative effect on NFP. Non-debt tax shields and volatility have a negative impact on the NFP, unless we examine the long-term debt, because in this latter case the relationship is positive.

Table 2. Regression results

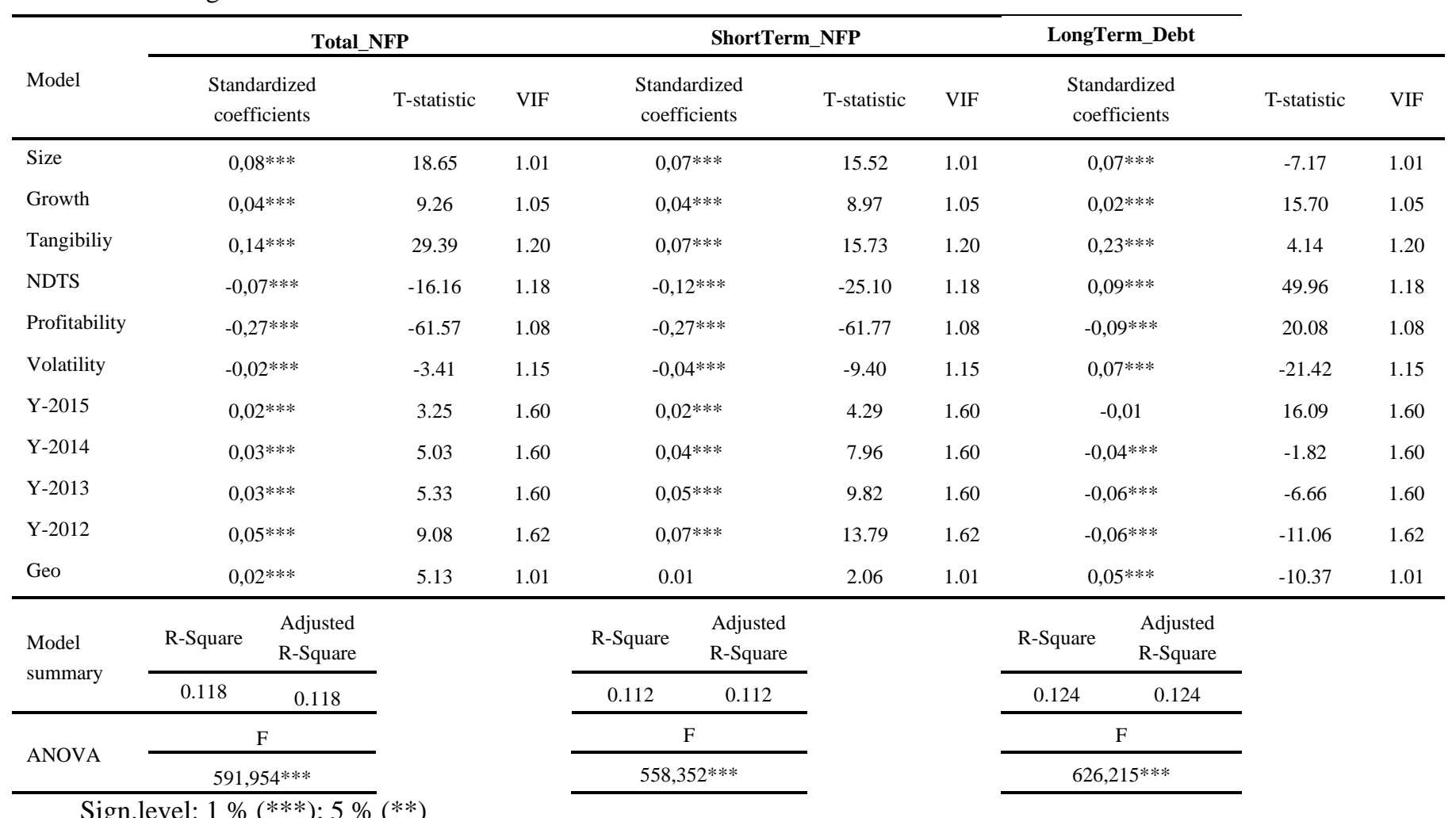

Furthermore, among our research purpose, there was the one to compare firms performance before and after the deleverage process. In the next table we show the result concerning the T-Test used to compare the means of the same sample before and after 2012. Result shows that the ROE has substantially decreased since 2012 and that the ratio between the NFP and the Net Ebitda (which has been used as a proxy of the cash flow) has increased.

Table 3. T-Test results

\begin{tabular}{lllllc} 
& $2016-2012$ & $2007-2011$ & Difference & T-stat & Sig.(2-tailed) \\
\hline Roe & $6.4 \%$ & $8.7 \%$ & $-2.3 \%$ & 287.41 & 0,00 \\
\hline NFP/(Ebitda-tax) & 2.26 & 2.60 & -0.34 & 275.77 & 0,00 \\
\hline
\end{tabular}

\section{Conclusion}

Capital structure choices are one of the most addressed areas in corporate finance research. Although there is a broad existing literature concerning this topic for listed companies, less importance has been given to unlisted ones and to small and medium enterprises. However, the concern of this paper is not the financial structure and its determinants in non-financial firms, but the determinants of these choices, at firm level, in a setting of financial deleverage. According to the result of the study, Growth, Size, Tangibility and Profitability are associated with leverage, consistently with the previous literature. On the other hand, NDTS and Volatility are consistent with previous literature unless for their relationship with long-term debt. A possible explanation to these divergent results could be, on one hand, that long term financial decision are correlated with fixed assets and are difficult to be modified by management decisions in the same ways of short term debt and, on the other hand, because firms may have faced a 
higher volatility in the crisis period and didn't have time to change long term financial structure according to their new risk profile. Furthermore we found that the return on equity significantly decreased in the deleverage period, whereas firms had improved their debt service ratio.

The main contribution of this paper is related to the temporal setting in which the determinants of firms' capital structure has been investigated. In addition, the paper has a further important strength that is represented by the country in which the analysis has been made. Italy, indeed, has always been recognized as a bank-oriented country, where firms are heavily dependent on financial debt. An important change in firms' financial structure is, therefore, even more interesting in such a particular geographical setting.

However, the study has several limitations. We didn't control for industry classification, which in some previous works has been characterized to be significantly related to capital structure. In addition, some other variables could be added to the models, such as the difference between operating income and the cost of debt, to verify if firms had adjusted their financial structure to the leverage effect, since we know from Modigliani and Miller that if this difference is negative, firms may incur in a detrimental effect on the ROE, when they increase the financial debt-equity ratio. Furthermore, an indicator of bankruptcy, such as the Altman Z-score, could have been used to more directly verify the relationship between financial leverage and creditworthiness.

There are many further research opportunities apart from improving the present paper in the mentioned ways. The first possibility may be extending the study to other countries, since deleverage has been recognize as a European phenomenon and not just an Italian one. Furthermore, a more in depth analysis is needed to verify other changes in the capital structure. More specifically, we would warmly suggest investigation concerning changes in other source of financing, such as, for example, tax debt, bonds and equity contributions. This indication is also supported by the fact that we didn't found a decrease in firms' total assets during the period of investigation and this leads us to think that firms are financing their activity with resources provided by other players, thus substituting bank capital instead of reducing their overall debt.

\section{References}

Ang, J. S., Chua, J. H., \& McConnell, J. J. (1982). The administrative costs of corporate bankruptcy: A note. The Journal of Finance, 37(1), 219-226. https://doi.org/10.1111/j.1540-6261.1982.tb01104.x

DeAngelo, H., \& Masulis, R. W. (1980). Optimal capital structure under corporate and personal taxation. Journal of Financial Economics, 8(1), 3-29. https://doi.org/10.1016/0304-405X(80)90019-7

Gangi, F., \& Campanella, F. (2006). Basilea 2 nell'economia di impresa. Allocazione delle risorse, gestione dell'informazione e selezione aziendale. Carocci Editore.

Grossman, S. J., \& Hart, O. D. (1982). Corporate financial structure and managerial incentives. In The Economics of Information and Uncertainty, pp. 107-140. University of Chicago Press.

Gruber, M. J., \& Warner, J. B. (1977). Bankruptcy costs: Some evidence. The Journal of Finance, 32(2), 337-347. https://doi.org/10.1111/j.1540-6261.1977.tb03274.x

Jensen, M. C. (1986). Agency costs of free cash flow, corporate finance, and takeovers. The American Economic Review, 76(2), 323-329.

Jensen, M. C., \& Meckling, W. H. (1976). Theory of the firm: Managerial behavior, agency costs and ownership structure. Journal of Financial Economics, 3(4), 305-360. https://doi.org/10.1016/0304-405X(76)90026-X

Kraus, A., \& Litzenberger, R. H. (1973). A state-preference model of optimal financial leverage. The Journal of Finance, 28(4), 911-922. https://doi.org/10.1111/j.1540-6261.1973.tb01415.x

Modigliani, F., \& Miller, M. H. (1958). The cost of capital, corporation finance and the theory of investment. The American Economic Review, 48(3), 261-297.

Mustilli, M., Campanella, F., \& D'Angelo, E. (2017). Basel III and Credit Crunch: An Empirical Test with Focus on Europe. Journal of Applied Finance and Banking, 7(3), 47.

Myers, S. C. (1977). Determinants of corporate borrowing. Journal of Financial Economics, 5(2), 147-175. https://doi.org/10.1016/0304-405X(77)90015-0

Myers, S. C., \& Majluf, N. S. (1984). Corporate financing and investment decisions when firms have information that investors do not have. Journal of Financial Economics, 13(2), 187-221. https://doi.org/10.1016/0304-405X(84)90023-0

Rajan, R. G., \& Zingales, L. (1995). What do we know about capital structure? Some evidence from international data. The Journal of Finance, 50(5), 1421-1460. https://doi.org/10.1111/j.1540-6261.1995.tb05184.x

Titman, S., \& Wessels, R. (1988). The determinants of capital structure choice. The Journal of Finance, 43(1), 1-19. https://doi.org/10.1111/j.1540-6261.1988.tb02585.x 